It is the basic idea of going directly from electricity to a stable liquid energy storage medium which is so exciting. Further work must examine what energy losses are inevitable in the formic acid system to see whether they can be accepted and whether other losses can be avoided at acceptable cost. Electrochemical studies must also show whether by working under different conditions, for example, at higher temperatures and pressures, one could achieve a higher concentration of the acid (a $60 \%$ solution would contain more than half as much hydrogen on a volume basis as liquid hydrogen itself). It is by no means evident that the electrolytic liberation of hydrogen atoms in close proximity to $\mathrm{CO}_{2} \mathrm{~mol}$ ecules, leading to the formation of $\mathrm{HCOOH}$, should not at a suitable surface, proceed as efficiently at a given surface-specific rate as in the absence of $\mathrm{CO}_{2}$. In this case the atoms form hydrogen molecules, as in the electrolysis of water to form hydrogen gas at the cathode. And advanced electrolysis of water can achieve a high (75-90\%) efficiency of conversion of electrical energy into hydrogen (expressed as the heat of combustion to water), vastly higher than the authors' experiments seem to suggest for formic acid formation. A review of the electrochemical literature (Russell et al. J. Electrochem. Soc. 134, 1329; 1978) suggests that the authors' low efficiencies and low specific rates of formic acid formation are expected for this type of electrode process, where the hydrogen atom must be liberated at a high over-voltage (also with very poor electrical efficiency) to be able to break open the $\mathrm{CO}_{2}$ molecule and react with it. One might get over this problem but it is apparent that considerable research is needed.

Meanwhile, it may certainly be reasonable for the authors to claim, as they do, that the system "represents an energy storage method of exceptional versatility and generality" but until much more work is done it is surely rather over-optimistic to state that it "will be important for the storage of elecrical energy whenever there are surpluses".

\section{European plant health}

\section{from a Correspondent}

THE introduction of plant pathogens into a country in which they are not normally present can have devastating economic or environmental consequences. To prevent the inadvertent introduction of serious pathogens, stringent and well-informed quarantine regulations are necessary. New quarantine measures for continental Europe and Britain have been proposed by the European and Mediterranean Plant Protection Organisation (EPPO $B u l$, special issue 1975) and the EPPO have recently published the first set $\mathrm{cf}$ data sheets on which these recommendations are based (EPPO Bull. $8(2) ; 1978)$. These data sheets list some of the organisms covered by the quarantine regulations which are classified as A1 (organisms not present in the EPPO area) and A2 (present in the EPPO area). They provide a description of the pathogens and some of the diseases they cause.

At first glance this appears a commendable piece of work, but is it? One deficiency, which has caused widespread concern amongst plant pathoingists who have the task of interpreting the regulations is that variations in strain, race and serotype are ignored. The potential importance of such differences can be seen in British hedgerows, now lined with rows of dead elms as the result of the introduction of a variant strain of a pathogen already classified as endemic within Europe (including Britain).

With regard to the diseases with a viral aetiology the picture is confused by the lack of any reference to a definitive description of the virus such as the AAB/Commonwealth Mycological Institute Descriptions of Plant Viruses, and by the omission of any description of the morphology, composition, grouping or serological grouping of the virus. How then is anyone to know exactly which virus is being referred to and in that case how can "an EPPO country take whatever action is necessary and reasonable to prevent introduction" (EPPO Bull. 1975 special issue). iously confused by the practice of naming the viruses after the disease they cause and it seems a shame that the EPPO have not learnt this lesson. For example they describe Scottish raspberry leaf curl as a 'completely different disease' from American raspberry leaf curl and attribute rose wilt syndromes to endemic A2 pathogen(s) when plainly this is unlikely to be the case.

In Britain and Holland no clear evidence that rose wilt or dieback was graft transmissible has been found (Phytopath Z. 79, 160; 1974; Neth. J. Pl. Path. 81, 187; 1975); whereas in
Plant virus nomenclature is notor-
New Zealand the pathogen was readily graft transmitted and some field spread has been recorded (N.Z.J. agric. Res. 14, 735; 1971; A. J. R. N. Z. Inst. Hort. (2), 16; 1974). In California rose spring dwarf (Pl. Dis. Reptr. 55, 294; 1971) was reported and described as a graft transmissible disease distinct from rose wilt (Pl. Dis. Reptr. 60, 183; 1976). In addition rose leaf curl, a distinct component of a disease complex which resembles rose wilt, has also been described in California (Pl. Dis. Reptr. 60, $178 ;$ 1976). The question therefore remains of what is rose wilt and which pathogens cause it. Poor graft union formation, stunting and proliferation are disorders that can be induced by many pathogens, physiological conditions and environmental factors in woody plants. In view of this, to suggest endemic A2 pathogenic causes and to recommend quarantine procedures on that basis is both naive and foolhardy. Quarantine procedures should be based on the aetiology of a disease, not on disease expression.

The EPPO Working Party also seems to be rather inconsistent in its recommendations for the control of A1 pathogens. For the control of needle cast of Japanese larch caused by Mycosphaerella larici-leptolepis they state that "the importation of larch from Japan should be prohibited". However, in respect of American plum line pattern virus they say that it is doubtful whether roguing of trees should be recommended. This contradicts the original recommendations for A1 organisms of taking necessary and reasonable action to prevent entry.

The lists of A1 and A2 pathogenic organisms are abysmally short when one considers the vast numbers of economically important pathogens that have been described throughout the world. It is to be hoped that EPPO will rapidly extend their lists and that the data sheets will provide more comprehensive and accurate information on these pathogenic organisms.

Quarantine measures can only be effective if those responsible for them are well informed. Bureaucrats with little understanding of plant protection must seek the guidance of leading research workers otherwise confusion will result.

Non-endemic pests and pathogens are being imported to Britain annually, and the situation in continental Europe is even worse. EPPO's function is to advise on the restriction of movement of pathogenic organisms into and within Europe without impairing plant trade. Let us hope that it will adopt the correct policies to fufil this role and not imitate the Plant Health Branch of our own Ministry of Agriculture, Fisheries and Food (see Nature 259, 449; 1976). 